\title{
ANALISA HUBUNGAN DINAMIS ANTARA RISIKO PEMBIAYAAN MUDHARABAH, RISIKO PEMBIAYAAN MUSYARAKAH, RISIKO PEMBIAYAAN MURABAHAH, DAN PROFITABILITAS PERBANKAN SYARIAH
}

\author{
Rianto Anugerah W. \\ UIN Sunan Ampel Surabaya \\ rianto.anugerah@uinsby.ac.id \\ Ainun Nadliroh \\ STAI Lukman Hakim
}

\begin{abstract}
Abstrak
Pertumbuhan pembiayaan Bank Syariah mendorong peningkatan potensi pendapatan serta potensi risiko bagi Bank Syariah itu sendiri. Pengelolaan pembiayaan yang baik untuk menjaga tingkat kesehatan Bank Syariah merupakan hal yang sangat penting. Pengelolaan risiko tentu dihadapkan pada dinamika permasalahan teknis di lapangan yang dinamis serta perubahan kebijakan untuk mengambil langkah-langkah mitigasi risiko dan peningkatan potensi pendapatan Bank Syariah. Untuk itu perlu dilakukan Analisa hubungan secara dinamis risiko pembiayaan terhadap kemampuan pembiayaan tersebut menghasilkan keuntungan. Penelitian ini menggunakan alat analisa regresi dinamis vector autoregression untuk melakukan analisa hubungan dinamis, dan pengaruh jangka Panjang terhadap setiap variabelnya. Hasil dari penelitian ini menunjukkan adanya evaluasi secara berkala dari pihak Bank Syariah untuk mendorong atau mengurangi jumlah pembiayaan dalam rangka menjaga nilai non-performing finance tetap sehat $(<5 \%)$.
\end{abstract}

Keyword: Risiko Pembiayaan, Mudharabah, Profit Abilitas

\section{PENDAHULUAN}

Bank Syariah di Indonesia mampu menunjukkan kemajuan yang signifikan dalam perekonomian Indonesia dalam waktu relative singkat. Hal ini juga didukung oleh peta populasi masyarakat Indonesia yang mayoritas adalah masyarakat muslim
Basis akad pembiayaan yang paling dominan di Indonesia antara lain adalah pembiayaan berbasis akad Mudharabah, Musyarakah dan Murabahah. Ketiga pembiayaan ini menunjukkan pertumbuhan yang cukup signifikan dalam periode 2013 hingga 2017. 


\begin{tabular}{|l|l|l|l|l|l|}
\hline \multicolumn{1}{|c|}{$\begin{array}{c}\text { Basis } \\
\text { Pembiayaan }\end{array}$} & $\mathbf{2 0 1 3}$ & \multicolumn{1}{|c|}{$\mathbf{2 0 1 4}$} & \multicolumn{1}{|c|}{$\mathbf{2 0 1 5}$} & \multicolumn{1}{|c|}{$\mathbf{2 0 1 6}$} & \multicolumn{1}{c|}{$\mathbf{2 0 1 7}$} \\
\hline Mudharabah & 154,119 & 168,327 & 178,427 & 175,720 & 186,748 \\
\hline Musyarakah & 414,003 & 541,778 & 655,441 & 800,765 & $1,057,392$ \\
\hline Murabahah & $1,223,747$ & $1,362,088$ & $1,420,767$ & $1,543,492$ & $1,728,268$ \\
\hline
\end{tabular}

Sumber: OJK - Statistik Perbankan Syariah Desember 2017

Pertumbuhan ini secara tidak langsung meningkatkan potensi pendapatan serta potensi kerugian yang dihadapi oleh perbankan Syariah. Peningkatan potensi kerugian atau risiko yang tinggi membutuhkan monitoring, evaluasi serta supervisi yang tinggi.

Pembiayaan Mudharabah dan pembiayaan Musyarakah adalah natural uncertainty contract product, dimana pembiayaan ini memiliki ketidakpastian dalam menghasilkan laba atau keuntungan dari dana yang telah disalurkan bank untuk membiayai proyek yang telah disepakati antara bank nasabah. Risiko pembiayaan atau yang disebut non performing finance (NPF) akan berpengaruh negatif terhadap profitabilitas perbankan syariah.

Berbeda dengan Pembiayaan Murabahah yang termasuk ke dalam natural certainty contract product, artinya pembiayaan ini mendatangkan kepastian dalam menghasilkan laba (profit) dari dana yang telah disalurkan bank untuk projek yang telah diepakati. Risiko pembiayaan dalam Murabahah ini akan berpengaruh positif terhadap profitbilits perbankan syariah. Oleh karena itu, pembiayaan inilah yang sering di terapkan oleh perbankan syariah di Indonesia.

Bank syariah harus memiliki sebuah sistem manajemen pengawasan risiko dengan segala tindakan pencegahan untuk meminimalisir yang ditimbulkan dari penyaluran pembiayaan Mudharabah dan Musyarakah serta produk pembiayaan yang lainnya sehingga bank dapat menghasikan profit yang optimal. Dalam Peraturan Bank Indonesia Nomor 13/2/PBI/2011 tanggal 2 November 2011 tentang Penerapan Manajemen Risiko bagi Bank Umum Syariah dan Unit Usaha Syariah, bank wajib menerapkan manajemen risiko secara efektif, baik secara invidual maupun secara bank secara konsolidasi dengan perusahaan anak.

Pengelolaan risiko tentu dihadapkan pada dinamika permasalahan teknis di lapangan serta perubahan kebijakan untuk mengambil langkah-langkah mitigasi risiko dan peningkatan potensi pendapatan Bank Syariah. Oleh karena itu, penelitian ini akan menganalisa hubungan dinamis dari risiko pembiayaan Mudharabah, risiko pembiayaan Musyarakah, risiko pembiayaan Murabahah dan profitabilitas perbankan syariah di 
Indonesia periode 2013-2017.

Dalam pemodelan ekonometrika dengan menggunakan berbagai variabel urut waktu, salah satu aspek yang perlu diperhatikan adalah keberadaan dinamika. Diantara berbagai variabel sangat mungkin terdapat hubungan yang bersifat dinamis. Nilai suatu variabel mungkin tidak hanya dipengaruhi oleh nilai variabel lain pada periode yang sama (disebut hubungan kontemporer) tetapi juga oleh nilai variabel (baik sendiri maupun lainnya) pada titik waktu yang berbeda. ${ }^{1}$ Penelitian ini menggunakan Model Vector Autoregression (VAR) untuk melakukan Analisa hubungan dinamis, dan pengaruh jangka Panjang terhadap adanya goncangan pengaruh suatu variabel ke variabel lainnya.

\section{HIPOTESIS}

Adapun hipotesis statistik dalam penelitian ini adalah sebagai berikut:

Ho : Tidak terdapat pengaruh positif signifikan antara risiko pembiayaan Mudharabah, risiko pembiayaan Musyarakah, risiko pembiayaan Murabahah dan profitabilitas perbankan syariah periode 2013-2017.

Ha : Terdapat pengaruh positif signifikan antara risiko pembiayaan Mudharabah, risiko pembiayaan Musyarakah, risiko pembiayaan Murabahah dan profitabilitas perbankan syariah periode 2013-2017

\section{HASIL DAN PEMBAHASAN}

\footnotetext{
${ }^{1}$ Moch. Doddy Ariefianto, Ekonometrika, (Jakarta: Penerbit Erlangga), hlm. 108.
}

Untuk menganalisis variabel-variabel tersebut, dalam penelitian ini model ekonometrika yang digunakan adalah Vector Auto Regression (VAR). Sebelum dilakukan analisis dengan model VAR, terlebih dahulu harus di lakukan uji Stasioneritas Data. Berikut hasil penelitian yang telah dilakukan:

\section{UJI STASIONERITAS}

Dalam data runtut waktu, uji stasioneritas data sangat dibutuhkan untuk menguji apakah data tersebut stasioner atau tidak. Data dapat dikatakan stasioner apabila data tersebut tidak mengandung akar-akar unit (unit roots). Syarat data runtut waktu dikatakan stasioner apabila data dari semua variabel stasioner pada satu tingkat. Tingkatan dalam uji stasioneritas ada tiga stasioner, yaitu stasioner pada tingkat level, tingkat first difference dan second difference. Apabila dalam tingkat level semua variabel lolos uji stasioner, maka model VAR dapat di lanjutkan. Apabila dalam tingkat level variabel tidak lolos uji stasioner, maka uji dapat dilanjutkan dengan uji stasioner pada tingkat first difference, begitu juga dengan tingkat second difference.

Dalam penelitian ini, penulis menggunakan uji stasioner pada tingkat level pada semua variabel yang di teliti. Apabila hasil tidak stasioner pada tingkat level, maka akan di uji pada tingkat first difference. Hasil uji stasioner pada tingkat level tersebut sebagai berikut:

\section{HASIL UJI STASIONERITAS}


PADA TINGKAT LEVEL

Dari uji stasioneritas data pada tingkat level yang dilakukan, hanya variabel risiko pembiayaan Mudharabah yang lolos uji stasioneritas, sedangkan variabel risiko pembiayaan Musyarakah, risiko pembiayaan Murabahah dan profitabilitas perbankan syariah tidak lolos pada tingkat level. Hal ini dapat dilihat dari nilai probabilitas variabel risiko pembiayaan Mudharabah kurang dari $0,05(\alpha<0,05)$ sehingga data tersebut dapat dikatakan stasioner. Sedangkan pada variabel risiko pembiayaan Musyarakah, risiko pembiayaan Murabahah dan profitabilitas perbankan syariah nilai probabilitasnya lebih besar dari 0,05 ( $\alpha>$ 0,05) sehingga data tersebut secara statistik tidak stasioner. Maka agar data dapat dikatakan stasioner, uji dilanjutkan dengan uji stasioner data pada tingkat first difference.

\section{HASIL UJI STASIONER PADA TINGKAT FIRST DIFFERENCE}

Dikarenakan pada uji stasioneritas data pada tingkat level variabel risiko pembiayaan Musyarakah, risiko pembiayaan

Murabahah dan profitabilitas perbankan syariah tidak stasioner, maka perlu dilakukan uji stasioneritas data pada tingkat first difference.

Dari hasil uji stasioner pada tingkat first difference yang dilakukan, variabel risiko pembiayaan Mudharabah, risiko pembiayaan Musyarakah, risiko pembiayaan Murabahah dan profitabilitas perbankan syariah lolos uji stasioner.

Hal ini dapat dilihat dari nilai probabilitas semua variabel kurang dari $\alpha=0,05$ sehingga data tersebut dapat dikatakan stasioner pada tingkat first difference, maka model VAR first difference dapat di lanjutkan.

\section{Hasil uji akar unit seluruh variabel sebagai berikut:}

Setelah dilakukannya uji stasioneritas data pada tingkat level maupun pada tingkat first difference, maka hasil uji stasioneritas data secara singkat dapat dilihat pada tabel berikut:

Tabel 4.1

Hasil Uji Stasioneritas

\begin{tabular}{|c|c|c|c|c|}
\hline \multirow{2}{*}{ Variabel } & \multicolumn{4}{|c|}{ Uji Akar Unit } \\
\cline { 2 - 5 } & \multicolumn{2}{|c|}{ Level } & $1^{\text {st }}$ Difference \\
\cline { 2 - 5 } & ADF & Prob & ADF & Prob \\
\hline MDRB & -2.988370 & $0.0418^{*}$ & -7.962730 & $0.0000^{*}$ \\
\hline MSYR & -1.906494 & 0.3272 & -7.522838 & $0.0000^{*}$ \\
\hline MRBH & -2.896927 & 0.0517 & -8.634951 & $0.0000^{*}$ \\
\hline
\end{tabular}




\begin{tabular}{|l|l|l|l|l|}
\hline ROA & -2.677084 & 0.0841 & -8.623967 & $0.0000^{*}$ \\
\hline
\end{tabular}

*Stasioner pada taraf nyata 5 persen

Sumber: Output olah data $E$ - views yang diolah kembali

Hasil uji akar unit seluruh variabel diatas menunjukkan bahwa pada uji stasioneritas variabel pembiayaan Mudharabah stasioner pada tingkat level, sedangkan risiko pembiayaan Musyarakah, risiko pembiayaan Murabahah serta ROA stasioner pada tingkat first difference sehingga model VAR dapat dilanjutkan karena salah satu variabel stasioner pada tingkat level.

\section{Penentuan Panjang Lag Optimum}

Penentuan panjang lag ini digunakan untuk mengetahui lamanya keterpengaruhan variabel yang satu dengan variabel yang lain. Hal ini dikarenakan dalam estimasi model VAR sangat penting untuk menentukan berapa panjang lag yang tepat dalam model VAR. Cara pemilihan lag yang sering digunakan adalah kriteria informasi. Lag maksimum terikat dengan jumlah observasi (T) dandapat dihitung dengan formula yang diberikan oleh Said dan Dickey (1984), yakni $\mathrm{T}^{1 / 3}$ (lag optimal adalah akar tiga dari T). Dari formula diatas dapat disimpulkan bahwa lag optimum adalah lag sembilan (9). Hasil uji panjang lag optimal adalah sebagai berikut:

\begin{tabular}{|c|c|c|c|c|c|c|}
\hline \multicolumn{7}{|c|}{ VAR Lag Order Selection } \\
\hline \multirow{2}{*}{\multicolumn{7}{|c|}{$\begin{array}{l}\text { Endogenous variables: RASIO_NPF_MDRB RASIO_NPF_MRBH } \\
\text { RASIO_NPF_MSYR ROA }\end{array}$}} \\
\hline & & & & & & \\
\hline \multicolumn{7}{|c|}{ Exogenous variables: $\mathrm{C}$} \\
\hline \multicolumn{7}{|c|}{ Date: 07/27/19 Time: 14:09 } \\
\hline \multicolumn{7}{|c|}{ Sample: 2013M01 2017M12 } \\
\hline \multicolumn{7}{|c|}{ Included observations: 51} \\
\hline Lag & $\log \mathrm{L}$ & LR & FPE & $\mathrm{AIC}$ & $\mathrm{SC}$ & HQ \\
\hline 0 & -215.1626 & NA & 0.063490 & 8.594613 & 8.746128 & 8.652511 \\
\hline \multirow[t]{2}{*}{1} & -114.3919 & 181.782 & 0.00229 & 5.270269 & 6.02784 & 5.55976 \\
\hline & & $6^{*}$ & $1 *$ & & $7 *$ & $2 *$ \\
\hline 2 & -99.06035 & 25.25188 & 0.002381 & 5.296484 & 6.660126 & 5.817572 \\
\hline 3 & -83.70888 & 22.87671 & 0.002520 & 5.321917 & 7.291621 & 6.074599 \\
\hline 4 & -76.08713 & 10.16232 & 0.003716 & 5.650476 & 8.226243 & 6.634753 \\
\hline 5 & -58.92303 & 20.19306 & 0.003931 & 5.604825 & 8.786655 & 6.820696 \\
\hline 6 & -37.63610 & 21.70433 & 0.003754 & 5.397494 & 9.185387 & 6.844960 \\
\hline 7 & -15.46740 & 19.12593 & 0.003769 & 5.155584 & 9.549541 & 6.834645 \\
\hline 8 & 12.98923 & 20.08703 & 0.003349 & 4.667089 & 9.667108 & 6.577744 \\
\hline 9 & 31.57937 & 10.20636 & 0.005317 & 4.56551 & 10.17160 & 6.707765 \\
\hline
\end{tabular}


*Nilai terkecil (menunjukkan lag yang dipilih)

Sumber: Output olah data

Hasil uji panjang lag menunjukkan bahwa hasil panjang lag optimal adalah satu (1) menurut statistik kriteria Sequential modified LR test statistic (LR), Final Prediction Error (FPE), Schwarz Informasion Criteterion (SC) dan Hannan Quin Information Criterion (HQ). Sedangkan menurut statistik kriteria Akaike Information Criterion (AIC) lag optimal adalah lag sembilan (9). Dalam hal ini peneliti akan menggunakan lag satu dan lag sembilan untuk melihat hasil pengujian secara menyeluruh.

\section{Uji Signifikansi Variabel}

Uji signifikansi variable dilakukan untuk mengetahui pengaruh dari masingmasing variabel independen terhadap variabel dependen tau sebaliknya. Dari uji signifikansi variabel diperoleh tabel sebagai berikut:

Tabel 4.2

Hasil Uji Signifikansi Variabel

\begin{tabular}{ccccc}
\hline & MDRB & MSYRH & MRBH & ROA \\
\hline MDRB (-4) & - & 2.09336 & - & - \\
MDRB (-6) & - & - & 2.44928 & - \\
MRBH (-2) & - & - & 2.40977 & - \\
MRBH (-8) & - & - & 2.21587 & - \\
MSYRH (-1) & - & 3.29147 & 2.53220 & - \\
MSYRH (-2) & - & - & -2.03749 & - \\
MSYRH (-9) & - & - & & 2.33001 \\
ROA (-1) & - & - & -2.13020 & - \\
ROA (-4) & - & - & 2.04665 & - \\
C & - & - & 2.03522 & - \\
\hline
\end{tabular}

Sumber: Output olah data E-Views yang diolah kembali

Dari output tabel tersebut terlihat bahwa variabel risiko pembiayaan Musyarakah (MSYRH) secara statistic signifikan dipengaruhi oleh MDRB (4), MSYRH (-1). Sedangkan hal yang sama juga terjadi untuk variabel profitabilitas (ROA) secara statistik signifikan dipengaruhi oleh MSYRH (9).

$\begin{array}{rcc}\text { Untuk } & \text { variabel } & \text { risiko } \\ \text { pembiayaan } & \text { Murabahah } & \text { justru }\end{array}$


sedikit berbeda karena dipengaruhi oleh ketiga variabel pada masa lalu yaitu MDRB (-6), MRBH (-2), MRBH (-8), MSYRH (-1), MSYRH (-2), ROA (-1), ROA (-4), dan konstanta $\mathrm{C}$.

\section{Uji Kausalitas Granger}

Tujuan dilakukannya uji kausalitas dalam penelitian ini adalah untuk melihat pengaruh antar variabel. Hal ini dilakukan karena dalam model VAR tidak membedakan antara variabel endogen dan variabel eksogen sehingga uji kausalitas dapat bermula dari ketidaktahuan keterpengaruhan antar variabel. Uji kausalitas dapat dilakukan dengan berbagai metode, namun dalam penelitian ini metode yang digunakan adalah metode Granger's Causality. Metode Granger's Causality digunakan untuk menguji adanya hubungan kausalitas antara dua variabel, baik hubungan satu arah maupun dua arah. Hasil kausalitas sebagai berikut:

\begin{tabular}{|c|c|c|c|}
\hline Null Hypothesis: & Obs & $\begin{array}{c}\text { F- } \\
\text { Statistic }\end{array}$ & Prob. \\
\hline $\begin{array}{l}\text { RASIO_NPF_MRBH does not Granger Cause } \\
\text { RASIO_NPF_MDRB }\end{array}$ & 51 & 1.22420 & 0.3152 \\
\hline $\begin{array}{l}\text { RASIO_NPF_MDRB does not Granger Cause } \\
\text { RASIO_NPF_MRBH }\end{array}$ & & 0.92638 & 0.5158 \\
\hline $\begin{array}{l}\text { RASIO_NPF_MSYR does not Granger Cause } \\
\text { RASIO_NPF_MDRB }\end{array}$ & 51 & 0.90678 & 0.5313 \\
\hline $\begin{array}{l}\text { RASIO_NPF_MDRB does not Granger Cause } \\
\text { RASIO_NPF_MSYR }\end{array}$ & & 1.67407 & 0.1366 \\
\hline ROA does not Granger Cause RASIO_NPF_MDRB & 51 & 0.22545 & 0.9884 \\
\hline RASIO_NPF_MDRB does not Granger Cause ROA & & 0.31859 & 0.9628 \\
\hline $\begin{array}{l}\text { RASIO_NPF_MSYR does not Granger Cause } \\
\text { RASIO_NPF_MRBH }\end{array}$ & 51 & 0.33932 & 0.9547 \\
\hline $\begin{array}{l}\text { RASIO_NPF_MRBH does not Granger Cause } \\
\text { RASIO_NPF_MSYR }\end{array}$ & & 3.32253 & 0.0057 \\
\hline ROA does not Granger Cause RASIO_NPF_MRBH & 51 & 0.86653 & 0.5637 \\
\hline RASIO_NPF_MRBH does not Granger Cause ROA & & 2.94466 & 0.0116 \\
\hline ROA does not Granger Cause RASIO_NPF_MSYR & 51 & 2.02016 & 0.0696 \\
\hline RASIO_NPF_MSYR does not Granger Cause ROA & & 0.15033 & 0.9974 \\
\hline
\end{tabular}


Dari hasil uji kausalitas yang diperoleh diatas, diketahui bahwa variabel yang memiliki kasualitas adalah variabel yang memiliki nilai probabilitas yang lebih kecil dariapa nilai $\alpha=0.05$ sehingga dapat diartikan bahwa suatu variabel akan mempengaruhi variabel lain. Dari hasil pengujian Granger diatas, dapat dilihat hubungan timbal balik kausalitas sebagai berikut:

a. Variabel risiko pembiayaan Mudharabah secara statistic tidak signifikan mempengaruhi risiko pembiayaan Murabahah begitu pula sebaliknya variabel risiko pembiayaan Murabahah secara statistic tidak signifikan mempengaruhi variabel risiko pembiayaan Mudharabah yang dibuktikan dengan nilai probabilitas lebih besar dari 0,05 (hasil keduanya adalah menerima Ho).

b. Variabel risiko pembiayaan Mudharabah secara statistic tidak signifikan mempengaruhi risiko pembiayaan Musyarakah begitu pula sebaliknya variabel risiko pembiayaan Musyarakah secara statistic tidak signifikan mempengaruhi variabel risiko pembiayaan Mudharabah yang dibuktikan dengan nilai probabilitas lebih besar dari 0,05 (hasil keduanya adalah menerima Ho).

c. Variabel risiko pembiayaan Mudharabah secara statistic tidak signifikan mempengaruhi profitabilitas perbankan syariah begitu pula sebaliknya variabel profitabilitas perbankan syariah secara statistic tidak signifikan mempengaruhi variabel risiko pembiayaan Mudharabah yang dibuktikan dengan nilai probabilitas lebih besar dari 0,05 (hasil keduanya adalah menerima Ho).

d. Variabel risiko pembiayaan Murabahah secara statistic tidak signifikan mempengaruhi risiko pembiayaan Musyarakah sehingga Ho diterima sedangkan variabel risiko pembiayaan Musyarakah secara statistic signifikan mempengaruhi risiko pembiayaan Murabahah sehingga Ho ditolak. Dengan demikian, bisa disimpulkan terjadi kausalitas searah antara variabel risiko pembiayaan Murabahah dan risiko pembiayaan Musyarakah. 
e. Variabel risiko pembiayaan Murabahah secara statistic tidak signifikan mempengaruhi variabel profitablitas perbankan syariah sehingga Ho diterima sedangkan variabel profitabilitas perbankan syariah secara statistik signifikan mempengaruhi risiko pembiayaan Murabahah sehingga Ho ditolak. Dengan demikian, bisa

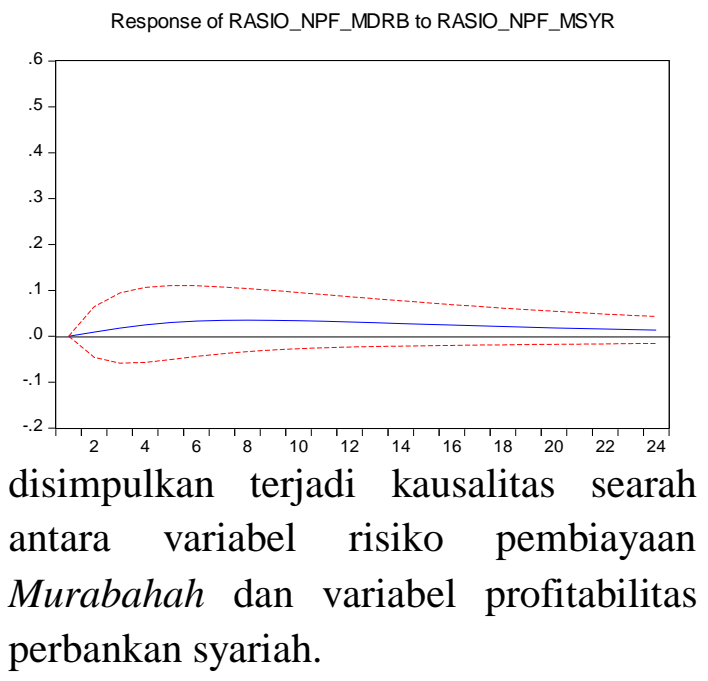

f. Variabel risiko pembiayaan Musyarakah secara statistik tidak signifikan mempengaruhi profitabilitas perbankan syariah begitu pula sebaliknya variabel profitabilitas perbankan syariah secara statistic tidak signifikan mempengaruhi variabel risiko pembiayaan Musyarakah yang dibuktikan dengan nilai probabilitas lebih besar dari 0,05 (hasil keduanya adalah menerima Ho).

\section{Impulse Response Function (IRF)}

Estimasi terhadap IRF ini digunakan untuk melihat respon suatu variabel terhadap suatu goncangan
Response of RASIO_NPF MDRB to RASIO NPF MDRB

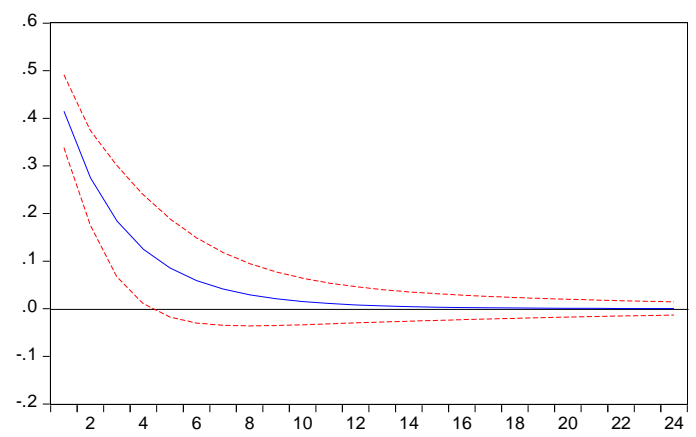

(shock) yang diakibatkan oleh variabel lain serta untuk melihat berapa lama periode pengaruh goncangan variabel tersebut setelah terjadi shock. Sumbu horisontal pada gambar dibawah menunjukkan periode waktu dimana satu periode mewakili satu bulan. Dalam hal ini, penulis menggunakan jangka waktu 24 periode dalam melakukan uji IRF. Sedangkan sumbu vertikal menunjukkan perubahan masing-masing variabel terhadap shock variabel tertentu dimana perubahan ini dinyatakan dalam satuan standar deviasi (SD). Berikut adalah gambar dari hasil uji IRF:

\section{a. Respon Risiko Pembiayaan}

\section{Mudharabah}
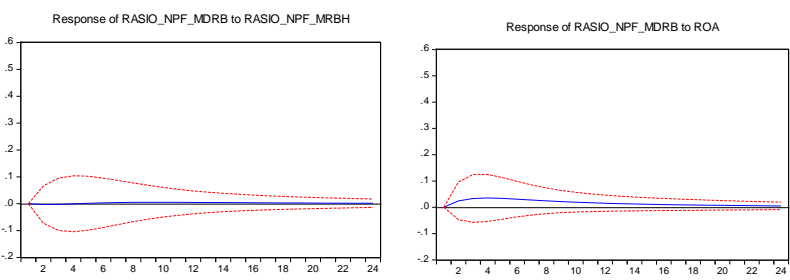

Pada awal periode yaitu bulan pertama sampai bulan ke-11 respon risiko pembiayaan Mudharabah terhadap profitabilitas perbankan syariah terlihat stabil sejak terjadinya goncangan (shock) pada variabel profitabilitas perbankan 
syariah. Jadi dampak shock profitabilitas perbankan terhadap risiko pembiayan Mudharabah terasa selama kurang lebih satu tahun lamanya. Selanjutnya, setelah satu tahun berlalu dampak shock mulai berkurang dan titik keseimbangan risiko pembiayaan Mudharabah sebelum adanya shock profitabilitas dapat dicapai mulai periode ke-19. Dari Grafik diatas terlihat bahwa respon risiko pembiayaan Mudharabah cenderung lebih cepat stabil dalam waktu kurang dari dua tahun setelah terjadi goncangan (shock) terhadap ketiga variabel lain. Hal ini menunjukkan bahwa ketiga variabel tidak signifikan mempengaruhi risiko pembiayaan Mudharabah.

b. Respon Risiko Pembiayaan Musyarakah

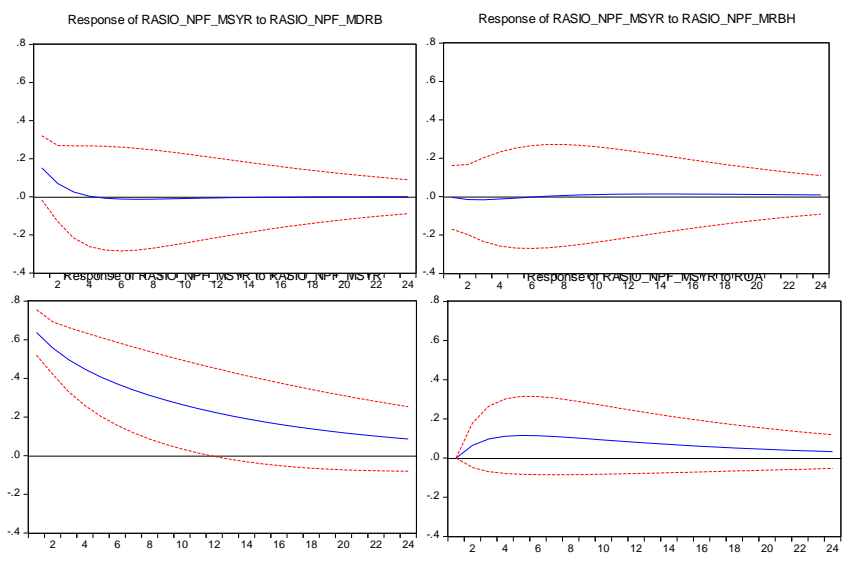

Dari Grafik diatas terlihat bahwa respon risiko pembiayaan Musyarakah terhadap risiko pembiayaan
Murabahah dan profitabilitas perbankan (ROA) cenderung lebih cepat stabil dibandingkan respon risiko pembiayaan Musyarakah terhadap risiko pembiayaan Mudharabah dan risiko pembiayaan Musyarakah itu sendiri dalam waktu dua tahun. Hal ini menunjukkan bahwa risko pembiayaan Murabahah dan profitabilitas perbankan (ROA) tidak signifikan mempengaruhi risiko pembiayaan Musyarakah.

\section{c. Respon Risiko Pembiayaan Murabahah}
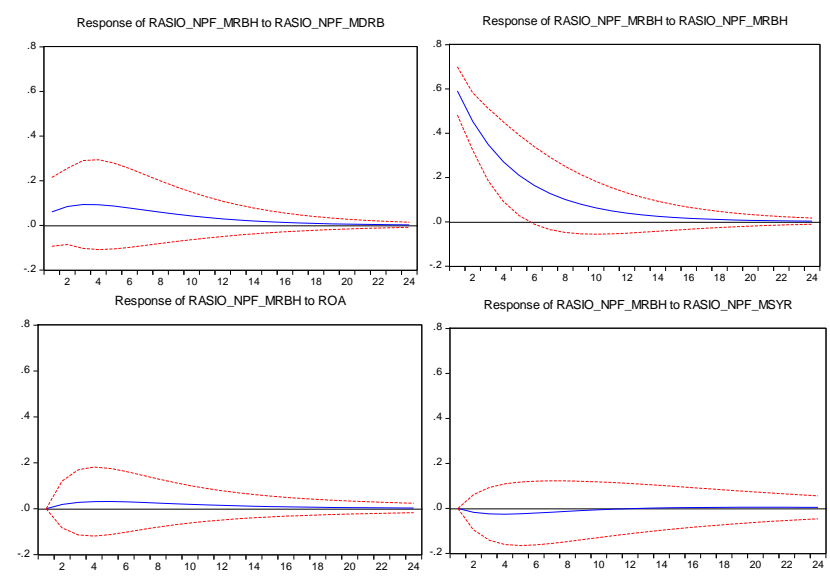

Dari grafik diatas bisa dilihat bahwa respon variabel risiko 
pembiayaan Murabahah terhadap ketiga variabel lainnya cenderung lebih cepat stabil dalam waktu dua tahun. Hal ini berlawanan dengan hasil uji signifikansi yang menyatakan bahwa ketiga variabel yang lain secara signifikan mempengaruhi risiko pembiayaan Murabahah. Hal ini bisa saja terjadi karena pada saat variabel risiko pembiayaan Mudharabah, risiko pembiayaan Musyarakah dan profitablilitas perbankan mengalami goncangan (shock), bank menambah jumlah pembiayaan Murabahah yang dikeluarkan untuk menutupi dampak dari goncangan dari ketiga variabel yang lain sehingga variabel risiko pembiayaan Murabahah akan cepat stabil meskipun terjadi goncangan pada ketiga variabel yang lain.

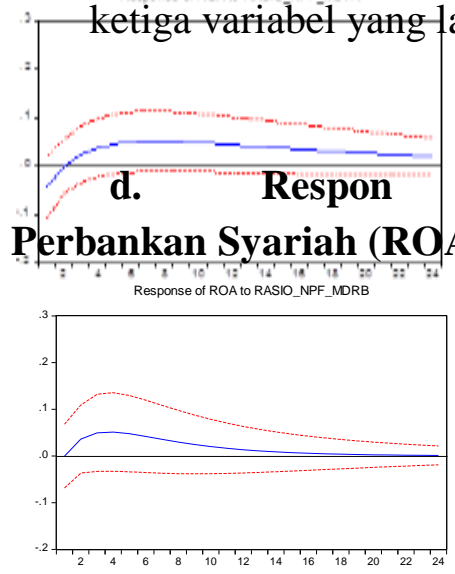

\section{Profitabilitas}

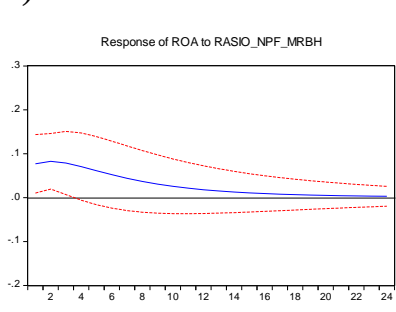

Dari grafik diatas bisa dilihat bahwa respon variabel profitabilitas perbankan (ROA) terhadap variabel risiko pembiayaan Mudharabah, risiko

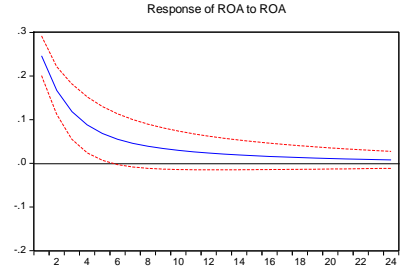

pembiayaan Murabahah, dan profitabilitas perbankan (ROA) itu sendiri lebih cepat stabil dibandingkan respon variabel profitabilitas perbankan terhadap variabel risiko pembiayaan Musyarakah dalam waktu dua tahun. Hal ini menunjukkan bahwa variabel risiko pembiayaan Mudharabah dan risiko pembiayaan Murabahah secara signifikan tidak mempengaruhi variabel profitabilitas perbankan (ROA).

\section{Variance \\ Decomposition (VDC)}

Uji variance decomposition atau Forecast Error Variance Decomposition (FEVD) digunakan untuk mengetahui bagaimana varian suatu variabel ditentukan oleh kontribusi dirinya sendiri maupun kontribusi variabel lain. Dalam permodelan VAR, Hasil FEVD dapat dilihat pada tabel berikut yang memeperlihatkan kontribusi variabel MDRB, MSYRH, MRBH, dan ROA. Berikut hasil uji FEVD sebagai sasaran akhir:

\section{a. Variance Decomposition (VDC) Risiko Pembiayaan Mudharabah}




\begin{tabular}{|c|c|c|c|c|c|}
\hline \multirow{3}{*}{$\begin{array}{l}\text { Peri } \\
\text { od }\end{array}$} & \multicolumn{5}{|c|}{ Variance Decomposition of RASIO_NPF_MDRB: } \\
\hline & S.E. & $\begin{array}{l}\text { RASIO } \\
\text { _NPF_MDR } \\
\text { B }\end{array}$ & $\begin{array}{r}\text { RASIO } \\
-{ }_{\text {NPF_MRB }} \\
\text { H }\end{array}$ & 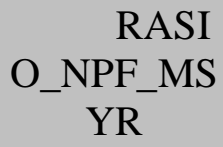 & ROA \\
\hline & 0.414960 & 100.0000 & 0.000000 & 0.000000 & 0.000000 \\
\hline & 0.498376 & 99.72114 & 0.003584 & 0.033363 & 0.241916 \\
\hline & 0.532665 & 99.24051 & 0.004766 & 0.141484 & 0.613242 \\
\hline 4 & 0.548796 & 98.66035 & 0.004498 & 0.338657 & 0.996493 \\
\hline 5 & 0.557253 & 98.04232 & 0.005449 & 0.615985 & 1.336249 \\
\hline 6 & 0.562226 & 97.42455 & 0.009026 & 0.950824 & 1.615596 \\
\hline 7 & 0.565516 & 96.83124 & 0.015170 & 1.316956 & 1.836635 \\
\hline 8 & 0.567926 & 96.27725 & 0.023048 & 1.691157 & 2.008541 \\
\hline 9 & 0.569826 & 95.77078 & 0.031678 & 2.055909 & 2.141632 \\
\hline 10 & 0.571396 & 95.31512 & 0.040258 & 2.399623 & 2.244996 \\
\hline 11 & 0.572724 & 94.91019 & 0.048262 & 2.715675 & 2.325875 \\
\hline 12 & 0.573863 & 94.55368 & 0.055414 & 3.001135 & 2.389773 \\
\hline 13 & 0.574844 & 94.24202 & 0.061617 & 3.255583 & 2.440778 \\
\hline 14 & 0.575691 & 93.97103 & 0.066888 & 3.480177 & 2.481903 \\
\hline 15 & 0.576422 & 93.73635 & 0.071307 & 3.676978 & 2.515370 \\
\hline 16 & 0.577053 & 93.53371 & 0.074977 & 3.848481 & 2.542832 \\
\hline 17 & 0.577596 & 93.35914 & 0.078010 & 3.997322 & 2.565526 \\
\hline 18 & 0.578063 & 93.20900 & 0.080509 & 4.126092 & 2.584395 \\
\hline 19 & 0.578465 & 93.08004 & 0.082566 & 4.237232 & 2.600163 \\
\hline & 0.578810 & 92.96936 & 0.084259 & 4.332983 & 2.613396 \\
\hline
\end{tabular}




\begin{tabular}{lllllll}
\hline 20 & & & & & \\
21 & 0.579106 & 92.87444 & 0.085656 & 4.415361 & 2.624539 \\
\hline 22 & 0.579361 & 92.79309 & 0.086809 & 4.486156 & 2.633949 \\
\hline 23 & 0.579579 & 92.72337 & 0.087764 & 4.546948 & 2.641915 \\
\hline 24 & 0.579766 & 92.66366 & 0.088557 & 4.599116 & 2.648670 \\
\hline
\end{tabular}

Berdasarkan tabel hasil FEVD diatas, pada periode pertama fluktuasi MDRB dipengaruhi oleh kontribusi MDRB itu sendiri sebesar 100 persen. Kemudian pada periode berikutnya, tampak kontribusi MDRB mulai dijelaskan oleh variabel-variabel lainnya. Kontribusi pada variabel lainnya mulai terlihat pada periode kedua dimana kontribusi terbesar adalah pada variabel ROA dengan kontribusi sebesar 0.2 persen, kemudian di lanjut dengan variabel MSYRH sebesar 0.03 persen dan variabel MDRB sebesar 0.003 persen.
Untuk periode selanjutnya, yaitu dapat kita lihat dari periode ke-3 sampai periode ke-24 kontribusi terbesar terhadap MDRB yaitu MSYRH dengan kontribusi sebesar 4.6 persen kemudian di susul dengan ROA sebesar 2.6 persen dan kontribusi terkecil pada $\mathrm{MRBH}$ sebesar 0.08 persen. Secara keseluruhan, variabel MSYRH, MRBH dan ROA hanya memiliki kontribusi yang kecil terhadap variabel

MDRB.

\section{a. Variance Decomposition (VDC) Risiko Pembiayaan Musyarakah}

\begin{tabular}{|c|c|c|c|c|c|}
\hline \multirow{3}{*}{$\begin{array}{l}\text { Peri } \\
\text { od }\end{array}$} & \multicolumn{5}{|c|}{ Variance Decomposition of RASIO NPF_MSYR: } \\
\hline & S.E. & $\begin{array}{c}\text { RASIO_NPF } \\
\text { _MDRB }\end{array}$ & $\begin{array}{c}\text { RASIO_NP } \\
\text { F_MRBH }\end{array}$ & $\begin{array}{c}\text { RASIO_NP } \\
\text { F_MSYR }\end{array}$ & ROA \\
\hline & 0.655803 & 5.396779 & 0.003230 & 94.59999 & 0.000000 \\
\hline & 0.866200 & 3.742407 & 0.033615 & 95.65981 & 0.564166 \\
\hline & 1.003616 & 2.852815 & 0.051535 & 95.73367 & 1.361980 \\
\hline 4 & 1.104620 & 2.355674 & 0.055558 & 95.44491 & 2.143859 \\
\hline
\end{tabular}




\begin{tabular}{|c|c|c|c|c|c|}
\hline & 1.182818 & 2.058794 & 0.052347 & 95.06268 & 2.826181 \\
\hline & 1.245072 & 1.867343 & 0.047548 & 94.69016 & 3.394953 \\
\hline 6 & 1.295495 & 1.734657 & 0.044253 & 94.36024 & 3.860847 \\
\hline 7 & 1.336815 & & 0.043603 & & 4.240754 \\
\hline 8 & 1.370963 & 1.562550 & 0.045620 & 93.84078 & 4.551047 \\
\hline 9 & & & & & \\
\hline 10 & 1.399368 & 1.503704 & 0.049825 & 93.64088 & 4.805587 \\
\hline 11 & 1.423112 & 1.456432 & 0.055587 & 93.47248 & 5.015506 \\
\hline 12 & 1.443041 & 1.417974 & 0.062307 & 93.33016 & 5.189561 \\
\hline 13 & 1.459821 & 1.386414 & 0.069488 & 93.20950 & 5.334602 \\
\hline 14 & 1.473987 & 1.360351 & 0.076750 & 93.10690 & 5.456002 \\
\hline 15 & 1.485972 & 1.338726 & 0.083825 & 93.01945 & 5.558001 \\
\hline 16 & 1.496131 & 1.320712 & 0.090536 & 92.94478 & 5.643976 \\
\hline 17 & 1.504753 & 1.305659 & 0.096775 & 92.88093 & 5.716639 \\
\hline 18 & 1.512081 & 1.293045 & 0.102488 & 92.82628 & 5.778188 \\
\hline 19 & 1.518316 & 1.282448 & 0.107657 & 92.77948 & 5.830419 \\
\hline 20 & 1.523625 & 1.273526 & 0.112289 & 92.73938 & 5.874808 \\
\hline 21 & 1.528150 & 1.266001 & 0.116410 & 92.70501 & 5.912581 \\
\hline 22 & 1.532008 & 1.259641 & 0.120053 & 92.67555 & 5.944755 \\
\hline 23 & 1.535300 & 1.254259 & 0.123258 & 92.65030 & 5.972183 \\
\hline 24 & 1.538110 & 1.249698 & 0.126065 & 92.62865 & 5.995582 \\
\hline
\end{tabular}

Berdasarkan tabel hasil FEVD diatas, kontribusi pada variabel 
lainnya mulai terlihat sejak periode pertama dimana kontribusi terbesar adalah pada variabel MDRB dengan kontribusi sebesar 5.4 persen, kemudian di lanjut dengan variabel MRBH sebesar 0.003 persen. Untuk periode selanjutnya, yaitu dapat kita lihat dari periode ke-2 sampai periode ke-24 kontribusi terbesar terhadap MSYRH yaitu ROA dengan kontribusi sebesar 5.9 persen kemudian di susul dengan MDRB sebesar 3.7 persen dan kontribusi terkecil pada MRBH sebesar 0.12 persen. Secara keseluruhan, variabel MDRB, MRBH dan ROA hanya memiliki kontribusi yang kecil terhadap MSYRH

\section{Variance Decomposition (VDC) Risiko Pembiayaan Murabahah}

\begin{tabular}{|c|c|c|c|c|c|}
\hline \multirow{3}{*}{$\begin{array}{l}\text { Peri } \\
\text { od }\end{array}$} & \multicolumn{5}{|c|}{ Variance Decomposition of RASIO_NPF_MRBH: } \\
\hline & S.E. & $\begin{array}{c}\text { RASIO_NPF_ } \\
\text { MDRB }\end{array}$ & $\begin{array}{c}\text { RASIO_NPF } \\
\text { _MRBH }\end{array}$ & $\begin{array}{c}\text { RASIO_NPF } \\
\text { _MSYR }\end{array}$ & ROA \\
\hline & 0.594246 & 1.040153 & 98.95985 & 0.000000 & 0.000000 \\
\hline & 0.752549 & 1.919143 & 97.96866 & 0.052011 & 0.060181 \\
\hline & 0.835653 & 2.805400 & 96.90998 & 0.127075 & 0.157543 \\
\hline & 0.884054 & 3.603595 & 95.93410 & 0.198257 & 0.264051 \\
\hline & 0.913632 & 4.271814 & 95.10950 & 0.254283 & 0.364399 \\
\hline & 0.932188 & 4.802963 & 94.45229 & 0.293072 & 0.451677 \\
\hline 0 & 0.944009 & 5.209046 & 93.95003 & 0.316988 & 0.523939 \\
\hline 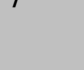 & 0.951609 & 5.510228 & 93.57802 & 0.329898 & 0.581856 \\
\hline 0 & 0.956524 & 5.728237 & 93.30889 & 0.335608 & 0.627265 \\
\hline ? & 0.959714 & 5.882929 & 93.11753 & 0.337200 & 0.662337 \\
\hline & 0.961793 & 5.990889 & 92.98308 & 0.336871 & 0.689162 \\
\hline & 0.963152 & 6.065186 & 92.88922 & 0.336031 & 0.709558 \\
\hline
\end{tabular}




\begin{tabular}{lllllll}
\hline 12 & 0.964045 & 6.115705 & 92.82380 & 0.335472 & 0.725019 \\
13 & 0.964636 & 6.149692 & 92.77801 & 0.335560 & 0.736735 \\
\hline 14 & 0.965030 & 6.172339 & 92.74565 & 0.336388 & 0.745624 \\
\hline 15 & 0.965296 & 6.187294 & 92.72242 & 0.337895 & 0.752390 \\
\hline 16 & 0.965478 & 6.197079 & 92.70542 & 0.339945 & 0.757560 \\
\hline 18 & 0.965606 & 6.203420 & 92.69267 & 0.342382 & 0.761531 \\
\hline 19 & 0.965697 & 6.207485 & 92.68286 & 0.345052 & 0.764599 \\
\hline 21 & 0.965764 & 6.210056 & 92.67514 & 0.347824 & 0.766984 \\
\hline 22 & 0.965813 & 6.211653 & 92.66890 & 0.350593 & 0.768850 \\
\hline 23 & 0.965852 & 6.212622 & 92.66378 & 0.353281 & 0.770320 \\
\hline
\end{tabular}

ke-2 sampai periode ke-24 kontribusi terbesar terhadap MRBH yaitu MDRB dengan kontribusi sebesar 6.2 persen kemudian di susul dengan ROA sebesar 0.77 persen dan kontribusi terkecil pada MSYRH sebesar 0.35 persen.

Berdasarkan tabel hasil FEVD diatas, kontribusi pada variabel lainnya mulai terlihat sejak periode pertama dimana kontribusi terbesar adalah pada variabel MDRB dengan kontribusi sebesar 1 persen,. Untuk periode selanjutnya, yaitu dapat kita lihat dari periode
Secara keseluruhan, variabel MDRB, MSYRH dan ROA hanya memiliki kontribusi yang kecil terhadap MRBH.

\section{a. Variance Decomposition (VDC) Profitabilitas Perbankan Syariah}

\begin{tabular}{lcccc}
\hline & \multicolumn{4}{c}{ Variance Decomposition of ROA: } \\
S.E. & RASIO_NPF_ & RASIO_NPF & RASIO_NPF_ & ROA \\
Peri & MDRB & MRBH & MSYR & \\
\hline
\end{tabular}




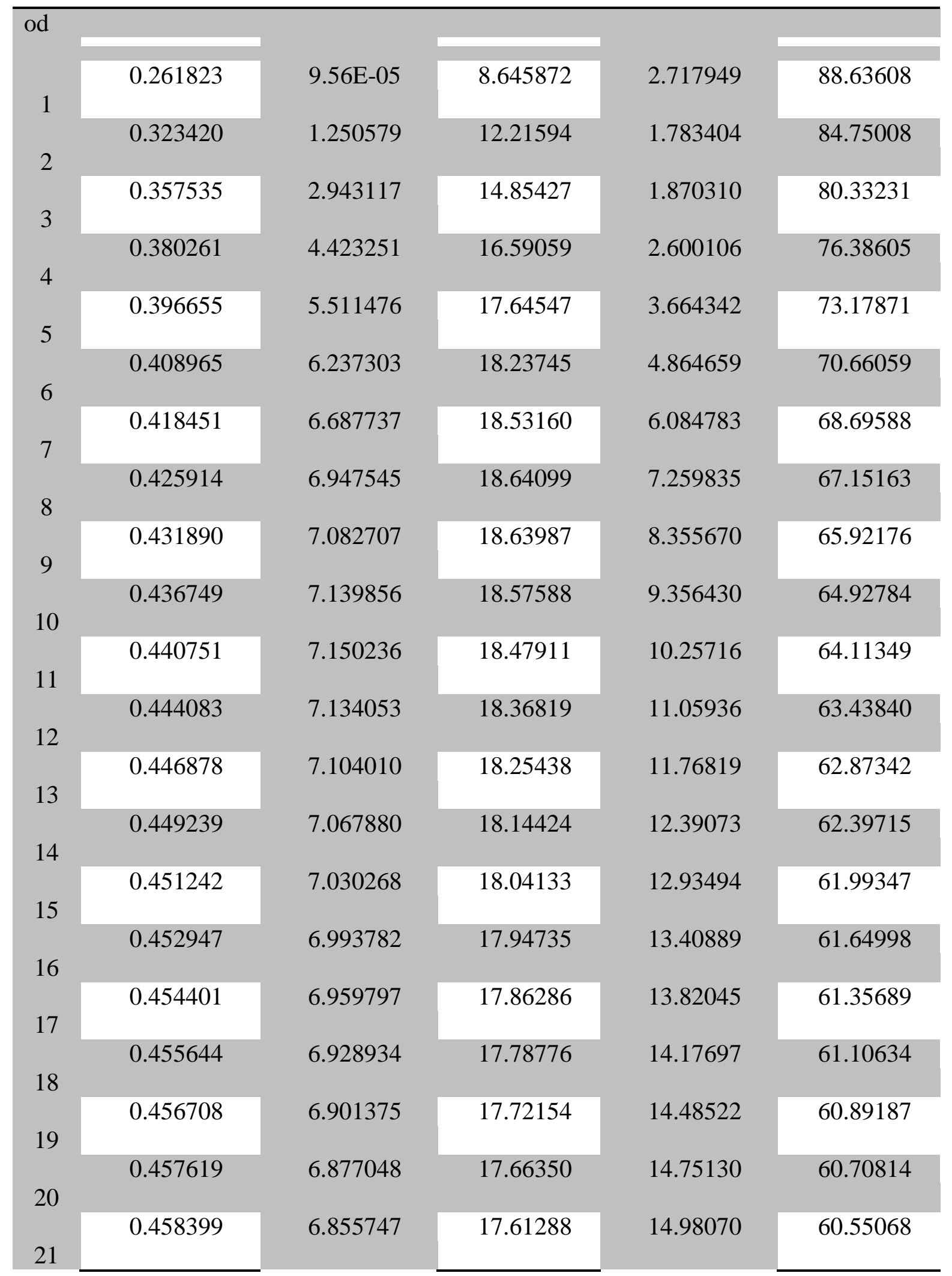




\begin{tabular}{llllll}
\hline 22 & 0.459068 & 6.837202 & 17.56888 & 15.17825 & 60.41567 \\
\hline 23 & 0.459641 & 6.821126 & 17.53074 & 15.34821 & 60.29992 \\
\hline & 0.460132 & 6.807231 & 17.49776 & 15.49434 & 60.20067 \\
\hline
\end{tabular}

Berdasarkan tabel hasil FEVD diatas, kontribusi pada variabel lainnya mulai terlihat sejak periode pertama dimana kontribusi terbesar adalah pada variabel MDRB dengan kontribusi sebesar 9.5 persen kemudian disusul oleh variabel MRBH dengan kontribusi sebesar 8.6 persen dan variabel MSYRH dengan kontribusi sebesar 2.7 persen. Untuk periode selanjutnya, yaitu dapat kita lihat dari periode ke-2 sampai periode ke-24 kontribusi terbesar terhadap ROA yaitu MRBH dengan kontribusi sebesar 18.6 persen kemudian di susul dengan MSYRH sebesar 15.4 persen dan kontribusi terkecil pada MDRB sebesar 7.1 persen. Secara keseluruhan, variabel MDRB, MSYRH dan MRBH hanya memiliki kontribusi yang kecil terhadap ROA.

\section{Pembahasan}

\section{Pengaruh}

\section{Dinamis Risiko \\ Pembiayaan Mudharabah}

Dari hasil uji signifikansi, variabel risiko pembiayaan Mudharabah secara statistik tidak signifikan dipengaruhi oleh ketiga variabel lainnya yaitu, risiko pembiayaan Musyarakah, risiko pembiayaan Murabahah dan profitabilitas perbankan (ROA). Pada uji kausalitas Granger tidak terjadi kausalitas searah maupun dua arah antara variabel risiko pembiayaan Mudharabah denngan ketiga variabel lain. Sedangkan pada fungsi impuls respon (IRF) respon risiko pembiayaan Mudharabah cenderung lebih cepat stabil dalam waktu kurang dari dua tahun setelah terjadi goncangan (shock) terhadap ketiga variabel lain. Hal ini menunjukkan bahwa ketiga variabel tidak signifikan mempengaruhi risiko pembiayaan Mudharabah. Variabel risiko pembiayaan Mudharabah secara signifikan hanya dipengaruhi oleh risiko pembiayaan Mudharabah itu sendiri seperti yang terlihat pada Variance Decomposition (VDC).

\section{Pengaruh Dinamis}

\section{Risiko Pembiayaan}

\section{Musyarakah}

Dari hasil uji signifikansi, variabel risiko pembiayaan Musyarakah secara statistik signifikan dipengaruhi oleh variabel risiko pembiayaan Mudharabah dan variabel risiko pembiayaan Musyarakah itu sendiri. Uji signifikansi dapat 
dimodelkan sebagai berikut:

MSYRH=2.09336 MDRB

$$
(-4)+3.29147 \text { MSYRH(-1) }
$$

Pada uji kausalitas granger terjadi kausalitas searah antara variabel risiko pembiayaan Musyarakah dengan variabel risiko pembiayaan Murabahah. Sedangkan pada fungsi impuls respon (IRF) respon risiko pembiayaan Musyarakah terhadap risiko pembiayaan Murabahah dan profitabilitas perbankan (ROA) cenderung lebih cepat stabil dibandingkan respon risiko pembiayaan Musyarakah terhadap risiko pembiayaan Mudharabah dan risiko pembiayaan Musyarakah itu sendiri dalam waktu dua tahun. Hal ini menunjukkan bahwa risko pembiayaan Murabahah dan profitabilitas perbankan (ROA) tidak signifikan mempengaruhi risiko pembiayaan Musyarakah. Variabel risiko pembiayaan Musyarakah secara signifikan dipengaruhi oleh risiko pembiayaan Musyarakah itu sendiri seperti yang terlihat pada Variance Decomposition (VDC).

Pada pengujian signifikansi juga diketahui bahwa risiko Musyarakah dipengaruhi oleh risiko Mudharabah di lag ke -4 atau MDRB (-4). Hal ini dimungkinkan terjadi karena adanya evaluasi tiga bulanan (triwulan) yang lakukan manajemen bank. Saat angka NPF pembiayaan Mudharabah mulai meningkat, dimungkinkan ada upaya pemindahan skim pembiayaan (restrukturisasi) dari pembiayaan berbasis Mudharabah menjadi Musyarakah. Pola ini menyebabkan adanya transfer risiko kepada skim pembiayaan yang lain, dalam hal ini risiko pembiayaan Mudharabah berpindah ke pembiayaan Musyarakah

Uji signifikansi juga menunjukkan risiko Musyarakah dipengaruhi oleh risiko (NPF) Musyarakah itu sendiri di lag ke 1 atau MSYR (-1). Hal ini menunjukkan adanya upaya manajemen bank untuk selalu memperbaiki tingkat NPF pada suatu skim pembiayaan.

\section{Pengaruh Dinamis} Risiko Pembiayaan Murabahah

Dari hasil uji signifikansi, variabel risiko pembiayaan Murabahah secara statistik signifikan dipengaruhi oleh ketiga variabel lainnya yaitu, variabel risiko pembiayaan Mudharabah, risiko pembiayaan Musyarakah dan profitabilitas perbankan syariah (ROA). Uji signifikansi dapat dimodelkan sebagai berikut:

$\mathrm{MRBH}=2.44928 \mathrm{MDRB}(-6)+$ 2.40977 MRBH(2)+2.21587MRBH(8)+2.53220MSYRH(-1)-2.03749

$$
\text { MSYRH(-2) - 2.13020ROA(-1) + }
$$$$
2.04665 \mathrm{ROA}(-4)+2.03522 \mathrm{C}
$$

Pada uji kausalitas granger terjadi kausalitas searah antara variabel risiko pembiayaan Murabahah dengan variabel 
risiko pembiayaan Musyarakah dan variabel profitabilitas perbankan syariah (ROA). Sedangkan pada fungsi impuls respon (IRF), respon variabel risiko pembiayaan Murabahah terhadap ketiga variabel lainnya cenderung lebih cepat stabil dalam waktu dua tahun. Hal ini berlawanan dengan hasil uji signifikansi yang menyatakan bahwa ketiga variabel yang lain secara signifikan mempengaruhi risiko pembiayaan Murabahah. Hal ini bisa saja terjadi karena pada saat variabel risiko pembiayaan Mudharabah, risiko pembiayaan Musyarakah dan profitablilitas perbankan mengalami goncangan (shock), bank menambah jumlah pembiayaan Murabahah yang dikeluarkan untuk menutupi dampak dari goncangan dari ketiga variabel yang lain sehingga variabel risiko pembiayaan Murabahah akan cepat stabil meskipun terjadi goncangan pada ketiga variabel yang lain. Variabel risiko pembiayaan Murabahah secara signifikan dipengaruhi oleh risiko pembiayaan Murabahah itu sendiri seperti yang terlihat pada Variance Decomposition (VDC).

Pada uji signifikansi juga menunjukkan bahwa risiko murabahah dipengaruhi oleh nilai risiko (NPF) pembiayaan mudharabah di lag ke -6 atau MDRB (-6). Pola ini juga kemungkinan besar disebabkan oleh adanya transfer risiko kepada skim pembiayaan Mudharabah yang berpindah ke pembiayaan Murabahah. Lag ke -6 menunjukkan evaluasi yang dilakukan manajemen bank 6 periode (bulan) sebelumnya menyebabkan berpindahnya risiko Mudharabah ke nilai NPF Murabahah saat ini.

\section{Pengaruh Dinamis Profitabilitas Perbankan Syariah}

Dari hasil uji signifikansi, variabel profitabilitas perbankan syariah (ROA) secara statistik signifikan dipengaruhi oleh variabel risiko pembiayaan Musyarakah.

Uji signifikansi dapat dimodelkan sebagai berikut:

ROA= 2.33001MSYRH(-9)

Pada uji kausalitas granger disimpulkan terjadi kausalitas searah antara variabel risiko pembiayaan Murabahah dan variabel profitabilitas perbankan syariah (ROA). Sedamgkan pada fungsi impuls respon (IRF) respon variabel profitabilitas perbankan (ROA) terhadap variabel risiko pembiayaan Mudharabah, risiko pembiayaan Murabahah, dan profitabilitas perbankan (ROA) itu sendiri lebih cepat stabil dibandingkan respon variabel profitabilitas perbankan terhadap variabel risiko pembiayaan Musyarakah dalam waktu dua tahun. Hal ini menunjukkan bahwa variabel risiko pembiayaan Mudharabah dan risiko pembiayaan Murabahah secara signifikan tidak mempengaruhi variabel profitabilitas perbankan (ROA). Variabel profitabilitas perbankan syariah (ROA) secara signifikan 
dipengaruhi oleh profitabilitas perbankan syariah (ROA) itu sendiri seperti yang terlihat pada Variance Decomposition (VDC).

\section{KESIMPULAN}

Berdasarkan hasil penelitian dan analisis yang sudah dibahas pada bab sebelumnya mengenai profitabilitas perbankan syariah periode 2013-2017 di Indonesia, maka peneliti dapat menarik kesimpulan sebagai berikut:

1. Berdasarkan hasil dari kausalitas Granger, dapat disimpulkan bahwa terdapat hubungan kausalitas satu arah terhadap profitabilitas perbankan syariah di Indonesia khususnya pada periode Januari 2013 - Desember 2017.

Berdasarkan simulasi IRF dan VDC, respon profitabilitas perbankan syariah terhadap goncangan (shock) pada variabel risiko pembiayaan Mudharabah, risiko pembiayaan Musyarakah dan risiko pembiayaan Murabahah cukup baik. Berdasarkan hasil uji IRF, diketahui bahwa respon masing-masing variabel terhadap variabel lainnya mereda dan stabil pada periode kurang dari dua tahun. Sedangkan dari sisi besar kontribusinya, dapat dilihat dari hasil uji VDC bahwa variabel masing-masing variabel baik variabel risiko pembiayaan
Mudharabah, Musyarakah, Murabahah dan profitabilitas perbankan syariah memiliki kontribusi yang kecil terhadap variabel-variabel lainnya. Penerima kontribusi terkecil dari ketiga variabel lainnya adalah variabel risiko pembiayaan Mudharabah. Sedangkan penerima kontribusi terbesar dari ketiga variabel lainnya adalah variabel profitabilitas perbankan syariah. Selain itu variabel risiko pembiayaan Mudharabah merupakan variabel yang memiliki kontribusi terkecil dalam mendorong profitabilitas perbankan syariah di Indonesia, yaitu sebesar 6.8 persen. Hal ini dapat terjadi dikarenakan pada tahun periode penelitian, pembiayaan Mudharabah memiliki tingkat risiko yang cukup tinggi bagi perbankan syariah sementara permintaan pembiayaan Mudharabah cenderung positif. Sehingga kontribusi pembiayaan Mudharabah dalam meningkatkan profitabilitas perbankan syariah di Indonesia masih sangat kecil.

\section{DAFTAR PUSTAKA}

Kuncoro, Mudrajad. 2002. Manajemen Perbankan : Teori dan Aplikasi. (Yogyakarta : BPFE).

Undang - undang Perbankan No. 10 Tahun 1998 
A. Karim, Adiwarman. 2011.

Bank Islam : Analisis Fiih dan

Keuangan. (Jakarta : Rajawali Pers).

Antonio, Muhammad Syafi"I. 2001. Bank Syariah: Dari Teori Ke Praktik. (Jakarta: Gema Insani Pers)..

Rivai, Veithzal. 2013. Islamic

Risk Management For Islamic Bank: Risiko bukan untuk ditakuti, tapi dihadapi dengan cerdik, cerdas, dan profesional. (Jakarta: Gramedia Pustaka Utama).

Sudana , I Made. 2011. Manajemen Keuangan Perusahaan. (Jakarta : Erlangga).

Agus Harjito dan Martono. 2007. Manajemen Keuangan, (Yogyakarta : Ekonisia).

Husaini Usman dan Purnomo. 2008. Metodologi Penelitian Sosial. (Jakarta : PT Bumi Aksara)

Bungin, Burhan. 2001. Metodologi Penelitian Sosial : Format-format Kuantitatif dan Kualitatif. (Surabaya : Airlangga University Press).

Ghazali, Imam. 2006. Analisis Multivariate dengan Program SPSS. Ed.1. (Semarang: BPUD).

Nachrowi dan Usman. 2006. Pendeketan Ekonometrika untuk Analisis Ekonomi dan Keuangan. (Jakarta: Lembaga Penerbit Fakultas Ekonomi Univesitas Indonesia).
Santoso, Singgih. 2000. Buku Latihan SPSS Statistik Parametrik. (Jakarta: PT Elex Media Komputindo).

Ariefianto, Doddy. 2012. EKONOMETRIKA. (Jakarta: Penerbit Erlangga)
Vol. 9 No. 2 Oktober 2019 